\title{
Effects of heating on the secondary structure of proteins in milk powders using mid-infrared spectroscopy
}

\author{
M. P. Ye, ${ }^{* 1}$ R. Zhou, ${ }^{*}$ Y. R. Shi, ${ }^{*}$ H. C. Chen, ${ }^{*}$ and Y. Du† \\ ${ }^{*}$ College of Optical and Electronic Technology, China Jiliang University, Hangzhou 310018, PR China \\ †Information Engineering School, Hangzhou Dianzi University, Hangzhou 310018, PR China
}

\begin{abstract}
Milk powder is an important source of protein for adults and children. Protein is very sensitive to heat, which may influence people's usage of nutrients in milk powder. In this study, we describe the temperatureinduced secondary structure of protein in milk powders. In this study, whole milk powder containing $24 \%$ protein and infant formula containing $11 \%$ protein were heated from 25 to $100^{\circ} \mathrm{C}$. Attenuated total reflectance (ATR) spectra in the mid-infrared range $400-4,000 \mathrm{~cm}^{-1}$ were used to evaluate the heat effect on the secondary structure of protein in these 2 milk powders. The spectral changes as a function of temperature were maintained by difference spectra, second-derivative spectra and Gauss curve-fitted spectra. The secondary structures of protein in the whole milk powder began to change at $70^{\circ} \mathrm{C}$ and in the infant formula at $50^{\circ} \mathrm{C}$. The $\beta$-sheet and $\beta$-turn structures in the whole milk powder both decreased in the range of 70 to $85^{\circ} \mathrm{C}$, whereas $\alpha$-helix structures increased. The loss of $\beta$-sheet and $\beta$-turn may contribute to the formation of $\alpha$-helix in the whole milk powder. In infant formula powder, the $\beta$-sheet structure showed a decrease and then increase, whereas the $\beta$-turn structure showed an increase and then decrease in the range of 50 to $75^{\circ} \mathrm{C}$, and no change was found for $\alpha$-helix structures. This implies that heating may induce the transformation from $\beta$-sheet to $\beta$-turn. Overall, whole milk powder had better temperature stability than infant formula powder, probably because of the lower content of lipid in the former than in the latter. These results help us understand the thermal stability of protein in milk powder.
\end{abstract}

Key words: protein secondary structure, temperature, milk powder, mid-infrared spectroscopy

Received May 11, 2016.

Accepted October 4, 2016.

${ }^{1}$ Corresponding author: manpingye@cjlu.edu.cn

\section{INTRODUCTION}

Milk powder has high nutritional value and some useful functional properties. Milk powder contains several types of proteins, including mucins, caseins, and whey proteins (Malacarne et al., 2002; Haug et al., 2007). The nutrients in milk can be utilized exceptionally well; some of the factors may be the presence of proteins in milk. The proteins provide not only adequate amounts of essential amino acids but also biological activities from antimicrobial effects to immunostimulatory functions (Lönnerdal, 2003).

Milk powder has a long shelf life (up to $12 \mathrm{mo}$ ) at room temperature. However, loss of solubility occurs gradually during storage (Anema et al., 2006; Havea, 2006), which may be linked to conformational modification of protein molecules during processing and storage (Kher et al., 2007). It is a common practice to mix milk powder with hot water before feeding or drinking. The effects of hot water on the milk structure and nutrition is unclear.

Milk-based infant formulas, both liquid and powder, are very sensitive to heat damage (Puig et al., 2003). Heat treatment of human milk will influence some of its protective constituents (immunoglobulin, lactoferrin, lysozyme, and others; Ford et al., 1977). When whole milk proteins are heated (Kim and Jimenez-Flores, 1995), $\beta$-LG and other milk serum proteins interact with milk fat globule membrane proteins. As the temperature of bovine $\beta$-CN increases, the protein secondary structure turns and extended structure are stable, whereas loops and helices are unstable. The $\beta$-sheets and $\beta$-turns probably form a supporting hydrophobic core (Farrell et al., 2001). The effect of storage temperature on the solubility of milk protein concentrate showed that insolubility could be due to cross-linking of the proteins at the surface of the powder (Anema et al., 2006). The formation of heat-induced whey protein complexes in milk increases the $\mathrm{pH}$ of gelation and the firmness of acid milk gels (Morand et al., 2012). The increased capacity of milk proteins to bind curcumin after heat treatment can be attributed to whey pro- 
tein denaturation, as whey proteins bind to the surface of casein micelles with heating (Yazdi and Corredig, 2012).

Mid-infrared spectroscopy (from 400 to $4,000 \mathrm{~cm}^{-1}$ ) is a vibrational spectroscopy method that can reveal a wealth of information about the constituents in molecules, including proteins (Barth and Zscherp, 2002; Etzion et al., 2004; Barth, 2007). Mid-infrared spectroscopy is an efficient method widely used to predict milk fat, protein, lactose, and more detailed milk composition traits (Soyeurt et al., 2009; Rutten et al., 2011; De Marchi et al., 2014; Pappas et al., 2015; Toffanin et al., 2015; Visentin et al., 2015), as well as energy balance and feed efficiency (McParland et al., 2014). Modern infrared spectrometers are Fourier transform infrared (FTIR) spectrometers, which are similar to the Michelson interferometer (Arrondo et al., 1993). Fourier transform infrared spectrometry is a well-established method to probe the secondary structure of protein (Surewicz et al., 1993; Pelton and McLean, 2000; Barth and Zscherp, 2002; Li-Chan, 2007). The amide I band $\left(1,600-1,700 \mathrm{~cm}^{-1}\right)$ of protein is sensitive to changes in secondary structures (Byler and Susi, 1986; Carbonaro and Nucara, 2010; Majzner et al., 2013). The attenuated total reflectance (ATR) technique (Goormaghtigh et al., 1999) has advantages in measuring solid samples.

We used ATR-FTIR to detect the heat-induced changes of 2 milk powders: whole milk powder and infant formula. To avoid the interference of water (Etzion et al., 2004), we used milk powders directly as our experimental samples without mixing with water.

\section{MATERIALS AND METHODS}

\section{Apparatus and Materials}

The measurements were carried out using an FTIR spectrometer (Tensor 27, Bruker, Bremen, Germany), equipped with globar source, $\mathrm{KBr}$ beamsplitter, and deuterated triglycine sulfate detector. The crystal in the ATR attachment for the FTIR (Pike Technologies, Madison, WI) was germanium, and the angle of incidence was $45^{\circ}$. A press was used so that the milk powders could contact the crystal, avoiding trapped air. Infrared spectra were recorded with 16 scans in in $400-4,000 \mathrm{~cm}^{-1}$ range with a resolution of $4 \mathrm{~cm}^{-1}$. A vacuum blast-drying oven (DGG-9030A, Shanghai Senxin, Shanghai, China) was used to dry and heat the samples. The whole milk powder and infant formula (0-12 mo) were manufactured by the Inner Mongolia Yili Industrial Group Co. Ltd. (Hohhot, China), a wellknown corporation in the Chinese milk powder market and were purchased in a local supermarket.

\section{Methods}

Sixteen tubes in parallel, each with a volume of 10 $\mathrm{mL}$ and with $20 \mathrm{~g}$ of sample each, were put into the vacuum blast-drying oven and then heated at a rate of $5^{\circ} \mathrm{C} / \mathrm{min}$. The temperature was increased from 25 to $100^{\circ} \mathrm{C}$ at $5^{\circ} \mathrm{C}$ intervals (16 samples). One tube was taken out after the temperature had reached each preset cut-off temperature, capped immediately, and stored in a desiccator with silica gel. To guarantee the samples were completely heated, heating was maintained for 5 min. About 2 to $3 \mathrm{~g}$ of milk powder from each capped tube was placed on the ATR crystal for measurement.

A linear baseline was subtracted from each spectrum to give a straight baseline in the spectral region of $1,800-2,000 \mathrm{~cm}^{-1}$, and the spectra were smoothed with a 4-point Savitzky-Golay function to remove the possible white noise (Dong et al., 1990). For the secondary structure analysis, deconvolution of each spectrum was performed according to the methods of Fourier selfdeconvolution (Kauppinen et al., 1981) and the finite impulse response operator using the software Opus 6.5 (Bruker, Bremen, Germany). A spectrum of a single band that is characteristic of a secondary structure is broadened in the liquid or solid states. The bands overlapped and could not be distinguished from each other. Second derivatives of the amide I $\left(1,600-1,700 \mathrm{~cm}^{-1}\right)$ bands were used to indicate the position of individual component peaks of secondary structure within the amide I envelope. A curve-fitting procedure was used to estimate the area of each component representing secondary structures (Kumosinski and Farrell, 1993). The second derivatization and Gaussian curve fitting in the amide I region were analyzed using the software Origin 8.0 (OriginLab, Northampton, MA).

\section{RESULTS AND DISCUSSION}

\section{FTIR}

The mid-infrared spectra $\left(400-4,000 \mathrm{~cm}^{-1}\right)$ of whole milk and infant formula powders at $25^{\circ} \mathrm{C}$ are shown in Figure 1. The characteristic infrared spectral bands of the 2 milk powders were very similar. The absorption bands of 1,630 to $1,680 \mathrm{~cm}^{-1}$ and 1,510 to 1,570 $\mathrm{cm}^{-1}$ were from protein (Carbonaro and Nucara, 2010) assigned to $\mathrm{C}=\mathrm{O}$ stretching vibration absorption of amide I and $\mathrm{N}-\mathrm{H}$ and $\mathrm{C}-\mathrm{H}$ bending vibration absorption of amide II, respectively. The characteristic peaks of $2,920 \mathrm{~cm}^{-1}, 2,850 \mathrm{~cm}^{-1}$, and $1,743 \mathrm{~cm}^{-1}$ were from lipids in the milk powders, which can be assigned to the bands of antisymmetric $\mathrm{CH}_{2}$ stretching, symmetric $\mathrm{CH}_{2}$ stretching, and $\mathrm{C}=\mathrm{O}$ double-bond stretching, respec- 
tively (Mizutani et al., 2004; Zhou et al., 2006). The absorption bands located at 3,200 to $3,800 \mathrm{~cm}^{-1}, 1,030$ to $1,200 \mathrm{~cm}^{-1}, 900$ to $930 \mathrm{~cm}^{-1}$, and 755 to $785 \mathrm{~cm}^{-1}$ were attributed mainly to carbohydrate (Barth, 2007; Wenstrup et al., 2014). The NH stretching vibration gives rise to the amide $\mathrm{A}$ band of protein in the 3,200 to $3,800 \mathrm{~cm}^{-1}$ range (Barth and Zscherp, 2002).

The absorbance difference between whole milk powder and infant formula powder can be seen by focusing on the spectral window from 1,500 to $1,800 \mathrm{~cm}^{-1}$, as shown in Figure 2. In the spectrum of whole milk powder, the absorbance at $1,740 \mathrm{~cm}^{-1}$ was almost the same as that at the $1,540 \mathrm{~cm}^{-1}$ and $1,650 \mathrm{~cm}^{-1}$ bands. The absorbance ratios of $1,740 / 1,540 \mathrm{~cm}^{-1}$ and $1,740 / 1,650$ $\mathrm{cm}^{-1}$ were 0.81 and 1.08 , respectively. In the spectrum of infant formula powder, the absorbance at $1,743 \mathrm{~cm}^{-1}$ was much higher than that at $1,540 \mathrm{~cm}^{-1}$ and 1,650 $\mathrm{cm}^{-1}$. The absorbance ratios of $1,740 / 1,540 \mathrm{~cm}^{-1}$ and $1,740 / 1,650 \mathrm{~cm}^{-1}$ were 1.50 and 2.20 , respectively. Table 1 shows the ratio of the 3 absorbances for clarity, which indicates that the whole milk powder contained similar amounts of lipid and protein, whereas infant formula contained more lipid than protein, which is consistent with the contents indicated on the respective packages. As indicated on the label, $100 \mathrm{~g}$ of the whole milk powder contained $28 \mathrm{~g}$ of lipid and $24 \mathrm{~g}$ of protein, whereas $100 \mathrm{~g}$ of the infant formula contained $27 \mathrm{~g}$ of lipid and $11 \mathrm{~g}$ of protein. The percentages of lipid and protein are given in Table 1.

The presence of lipid in the milk powder does not make the spectroscopy of protein more complicated. Instead, lipid enhances the changes in protein because strong interactions occur between lipid and protein in a lipid-protein powder system. Mizutani et al. (2004) showed more drastic changes in protein secondary structures in a lipid-zein mixture than in zein only when powders were heated.

\section{Difference Spectra}

The mid-infrared absorption spectra of the whole milk and infant formula powders changed when the temperature was increased from $25^{\circ} \mathrm{C}$ to $100^{\circ} \mathrm{C}$. The underlying spectral changes as a function of temperature were easier to discern when these data were pre-

Table 1. The absorbance ratio and percentage of protein and lipid in the whole milk and infant formula powders

\begin{tabular}{lcc}
\hline Absorbance ratio & Whole milk & Infant formula \\
\hline $1,740 / 1,540\left(\mathrm{~cm}^{-1}\right)$ & 0.81 & 1.50 \\
$1,740 / 1,650\left(\mathrm{~cm}^{-1}\right)$ & 1.08 & 2.20 \\
Protein $(\%)$ & 0.24 & 0.11 \\
Lipid $(\%)$ & 0.28 & 0.27 \\
\hline
\end{tabular}

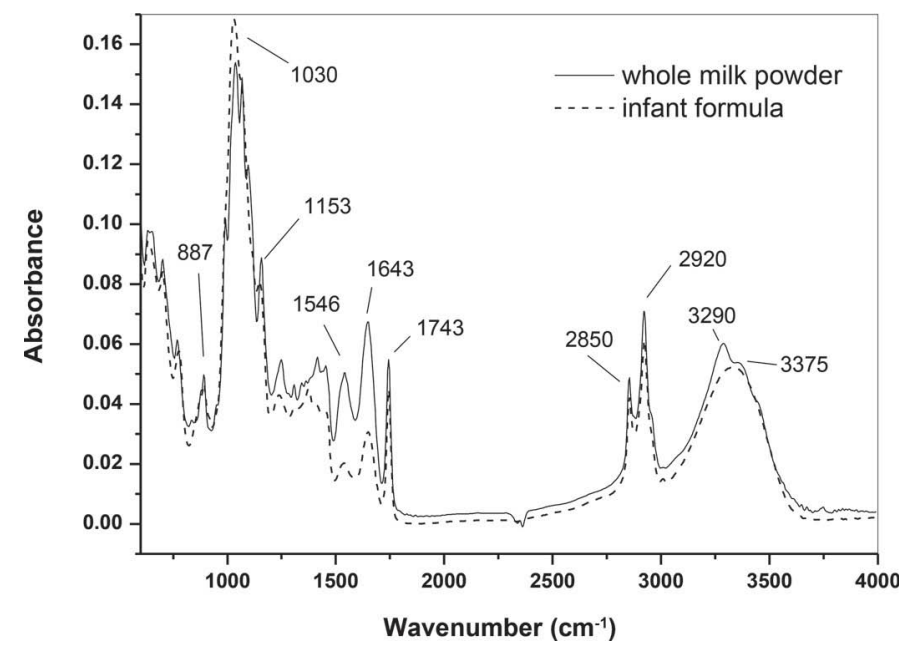

Figure 1. Fourier transform infrared (FTIR) spectra of whole milk and infant formula powders at $25^{\circ} \mathrm{C}$.

sented as difference spectra, generated by subtracting the spectrum at $25^{\circ} \mathrm{C}$ from those obtained at higher temperatures. To avoid interference from noise and mechanical drifting, baseline correction and smoothing were performed on the spectra. As shown in Figure 3a, the FTIR difference spectra of whole milk powder exhibited a positive feature in absorbance centered around $1,650 \mathrm{~cm}^{-1}$ at $45^{\circ} \mathrm{C}$, arising primarily from formation of $\alpha$-helical conformations with increasing temperature. This band disappeared and reappeared with increasing temperature. The band centered around $1,540 \mathrm{~cm}^{-1}$ exhibited a similar feature, whereas the band around $1,740 \mathrm{~cm}^{-1}$ showed a negative feature in absorbance and a new band around $1,750 \mathrm{~cm}^{-1}$ appeared as tem-

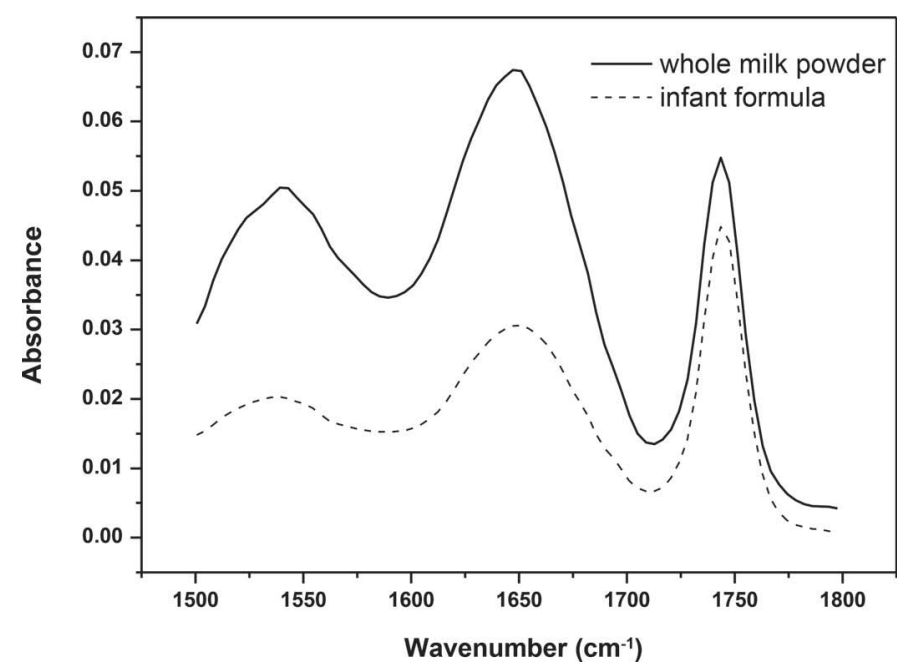

Figure 2. Fourier transform infrared (FTIR) spectra of whole milk and infant formula powders from 1,500 to $1,800 \mathrm{~cm}^{-1}$ at $25^{\circ} \mathrm{C}$. 
perature increased. Temperature-induced variations in backbone (lipid $\mathrm{C}=\mathrm{O}$ double-bond stretching) may shift the band of lipid toward a higher frequency ( $\mathrm{Yu}$ and Damiran, 2011). Different features were found in infant formula as indicated in Figure 3b. The FTIR difference spectra of infant formula powder displayed a negative feature centered around $1,650 \mathrm{~cm}^{-1}$ at $45^{\circ} \mathrm{C}$, resulting primarily from loss of $\alpha$-helical conformations with increasing temperature. The $\alpha$-helical structure partially reformed at higher temperatures. The band around $1,740 \mathrm{~cm}^{-1}$ showed the negative feature as that of whole milk powder. No higher frequency band of $1,740 \mathrm{~cm}^{-1}$ was observed for infant formula.

\section{Second-Derivative Spectra}

To elucidate the spectral differences, second-derivative spectra were used to find the number of secondary structure components and the approximate positions of these peaks (Kumosinski and Farrell, 1993). The second-derivative analysis can enhance the resolution for the spectra (Susi and Michael Byler, 1983). The second-derivative spectra were calculated using the Savitzky-Golay derivative algorithm. The frequencies at which amide I and amide II bands appeared were highly dependent on the secondary structure of the protein.

The peaks were assigned to different protein secondary structures. Peak assignment of amide I bands, which was shown in Table 2, was done according to the references (Pelton and McLean, 2000; Carbonaro and Nucara, 2010). Peaks between 1,620 and 1,640 $\mathrm{cm}^{-1}$ were assigned to $\beta$-sheets, $1,651 \mathrm{~cm}^{-1}$ to $\alpha$-helix, and between 1,660 and $1,695 \mathrm{~cm}^{-1}$ were assigned to $\beta$-turns. The peak at $1,697 \mathrm{~cm}^{-1}$ was assigned to unordered structures.

\section{Gauss Curve-Fitted Spectra}

According to the positions of negative peaks observed in Figure 4, we performed Gauss curve fitting on spectra after subtracting baseline from 1,600 to 1,700 $\mathrm{cm}^{-1}$. Figure 5 shows the results of Gauss curve fitting.

Table 2. Assignment of observed negative peaks to secondary structure $^{1}$

\begin{tabular}{ll}
\hline Observed negative peaks $\left(\mathrm{cm}^{-1}\right)$ & Corresponding secondary structure \\
\hline $1,624,1,627,1,639$ & $\beta$-Sheet \\
1,651 & $\alpha$-Helix, loop \\
$1,662,1,666,1,678,1,681,1,693$ & $\beta$-Turn \\
1,697 & Unordered \\
\hline
\end{tabular}

${ }^{1}$ Pelton and McLean (2000); Carbonaro and Nucara (2010).
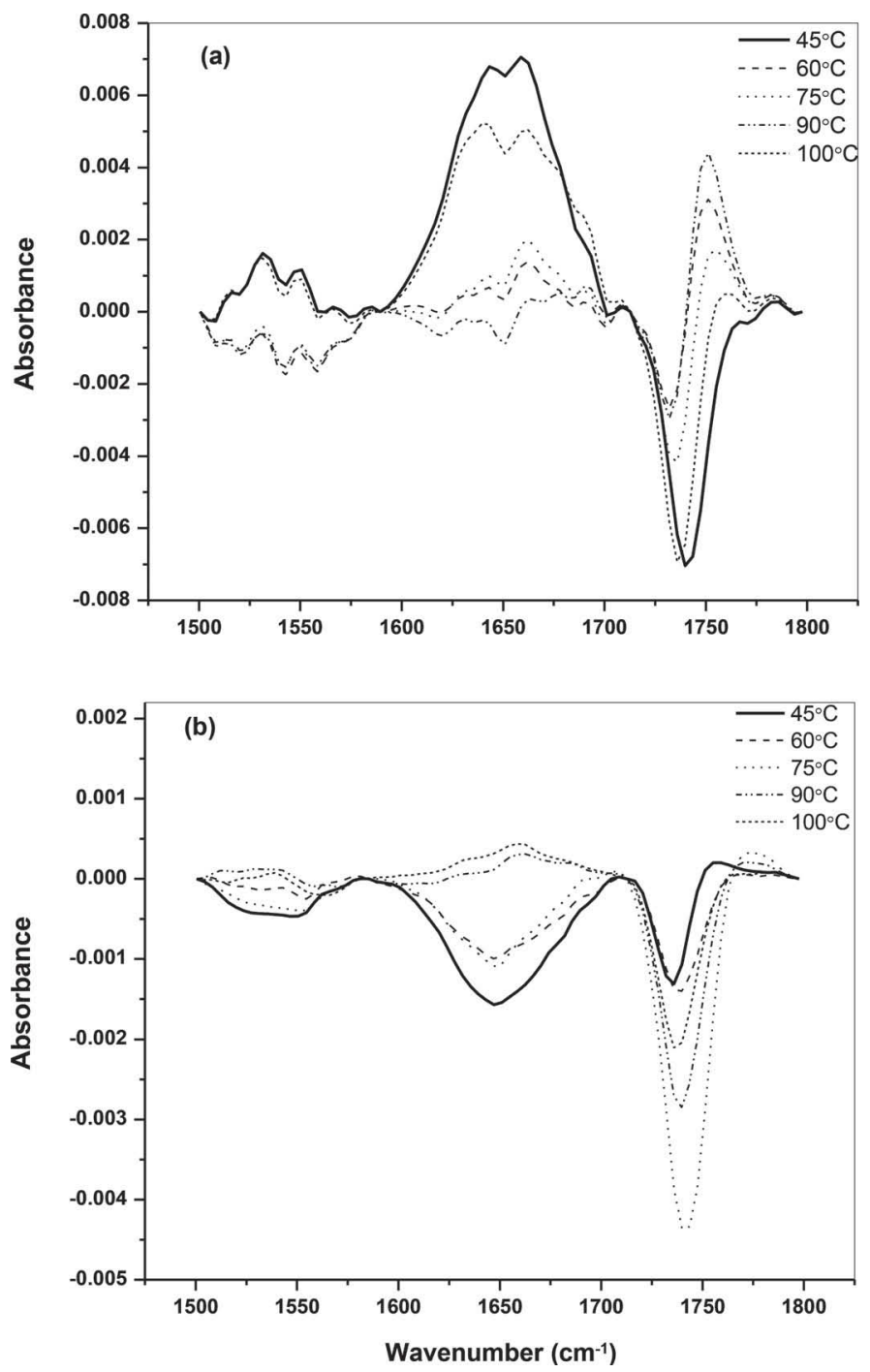

Figure 3. Fourier transform infrared (FTIR) difference spectra of (a) whole milk powder, and (b) infant formula powder generated by subtracting the spectra collected at $25^{\circ} \mathrm{C}$ from those collected at higher temperatures, as indicated.

The results demonstrate that despite differences in the contents of main ingredients between whole milk powder and infant formula powder as described above, the principal secondary structure contained in the 2 milk powders was very similar.

The relative contents of the secondary structures of protein were calculated from the areas of the individual bands of the Gauss curve-fitting results. Changes in the secondary structure at different temperatures for the 2 milk powders are illustrated in Figure 6. Relatively, the contents of $\beta$-sheet and $\beta$-turn for both milk powders were higher compared with $\alpha$-helix contents. Heating the 2 milk powders had different effects. In the case of whole milk powder, the contents of $\beta$-sheet, $\beta$-turn, and 


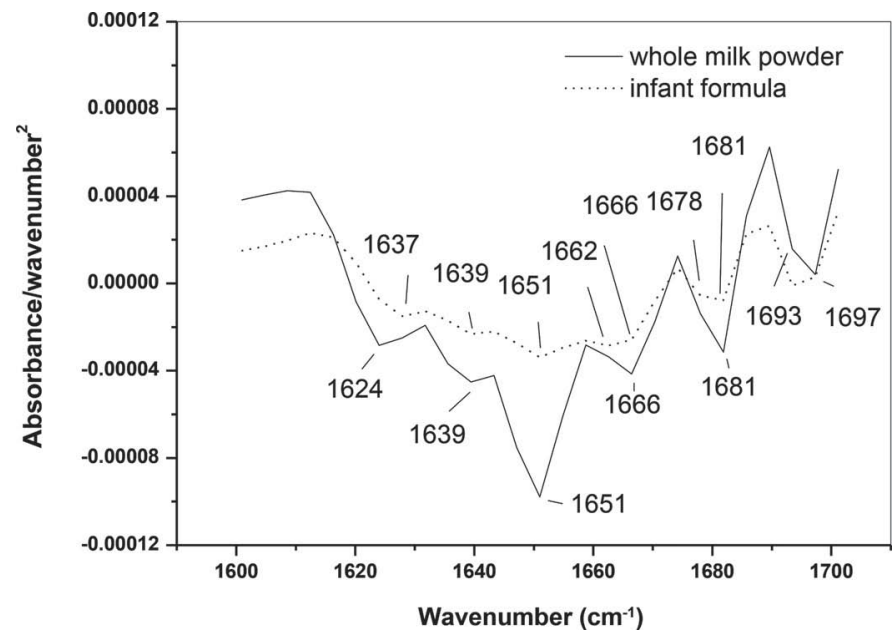

Figure 4. Second-derivative spectra of original attenuated total reflectance (ATR)-Fourier transform infrared (FTIR) spectra of whole milk and infant formula powders from 1,600 to $1,700 \mathrm{~cm}^{-1}$ at $25^{\circ} \mathrm{C}$. Negative peaks with small positive lobes represent different secondary structure components.

Q-helix showed substantial changes at $70^{\circ} \mathrm{C}$, whereas structures in infant formula changed at $50^{\circ} \mathrm{C}$. The $\beta$-sheet and $\beta$-turn structures in whole milk powder displayed decrease and recovery at 70 to $85^{\circ} \mathrm{C}$, whereas the $\alpha$-helix structure displayed increase and recovery at this temperature range. The loss of $\beta$-sheet and $\beta$-turn may contribute to the formation of $\alpha$-helix. In infant formula powder, the $\beta$-sheet structure showed a decrease and then increase, whereas the $\beta$-turn structure showed an increase and then decrease with the temperature increasing from 50 to $75^{\circ} \mathrm{C}$, which implies that the $\beta$-sheet and $\beta$-turn may transform to each other with heating. The relative content of $\alpha$-helix changed much less in infant formula than in whole milk powder, which may due to the lower content of protein in infant formula. Proteins are stable in their low-energy native (folded) state and aggregation via protein-protein or lipid-protein interactions will lead to destabilization (Arrondo and Goñi, 1999). Time-resolved mid-infrared spectroscopy is needed for future research to determine how quickly protein secondary structures change with heating.

\section{CONCLUSIONS}

Mid-infrared spectra technology was used to monitor the absorbance changes of whole milk and infant formula powders at different temperatures. The infant formula powder contained more lipid relative to protein, whereas the whole milk powder had similar lipid and protein contents. Both milk powders had higher proportions of $\beta$-sheet and $\beta$-turn structures than $\alpha$-helix structures. In whole milk powder, the $\beta$-sheet, $\beta$-turn, and $\alpha$-helix structures began to change at $70^{\circ} \mathrm{C}$, whereas changes in secondary structure in the infant formula began at $50^{\circ} \mathrm{C}$. Compared with infant formula powder, whole milk powder had better stability against heating. The lipid may help to maintain the protein structure when heated.

\section{ACKNOWLEDGMENTS}

The authors gratefully acknowledge the financial support from the National Science Foundation of China (Beijing; Grant No. 21103155).
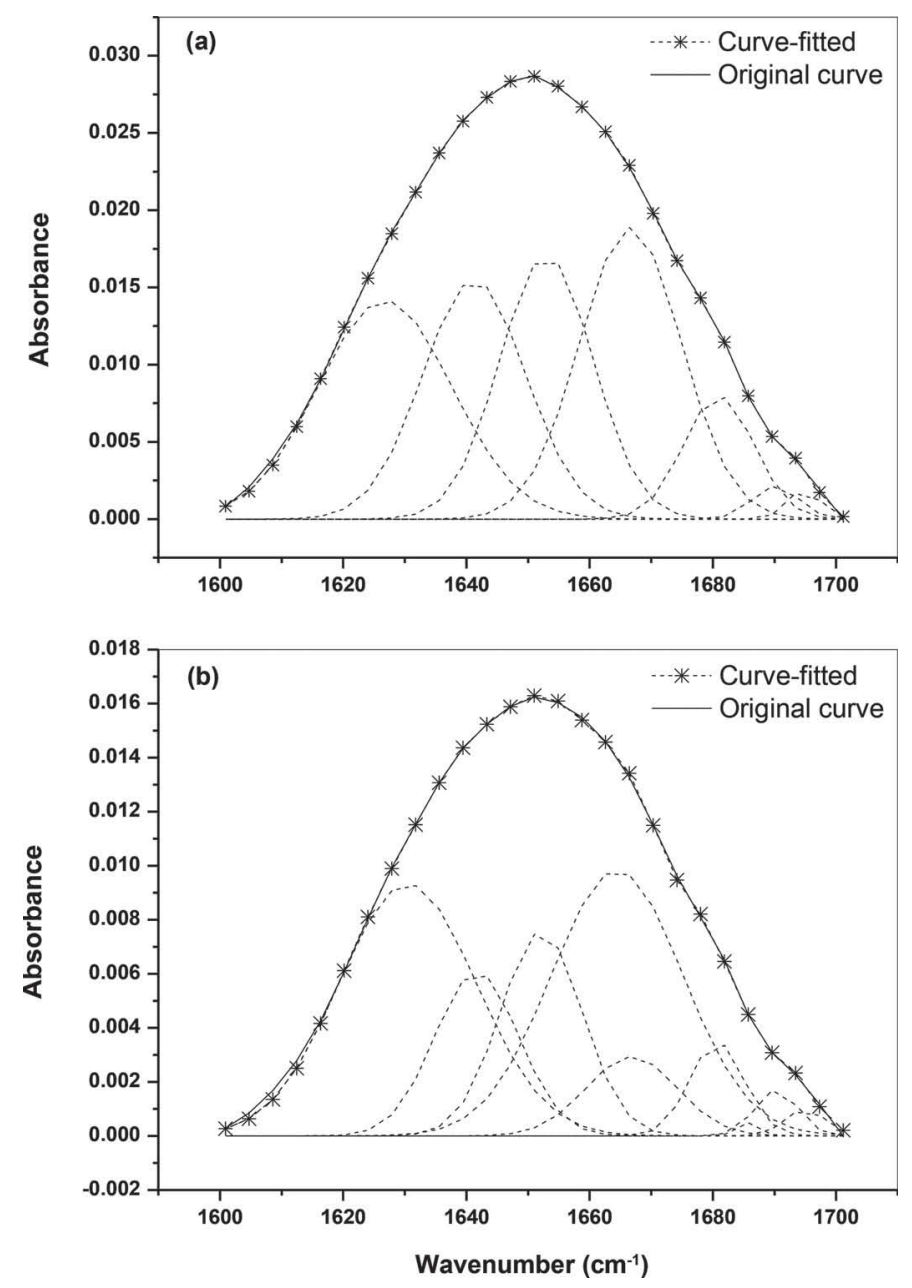

Figure 5. Gauss curve-fitted spectra of whole milk and infant formula powders. Gauss curve fitting was performed on spectra of whole milk and infant formula powders after subtracting the baseline from 1,600 to $1,700 \mathrm{~cm}^{-1}$. 

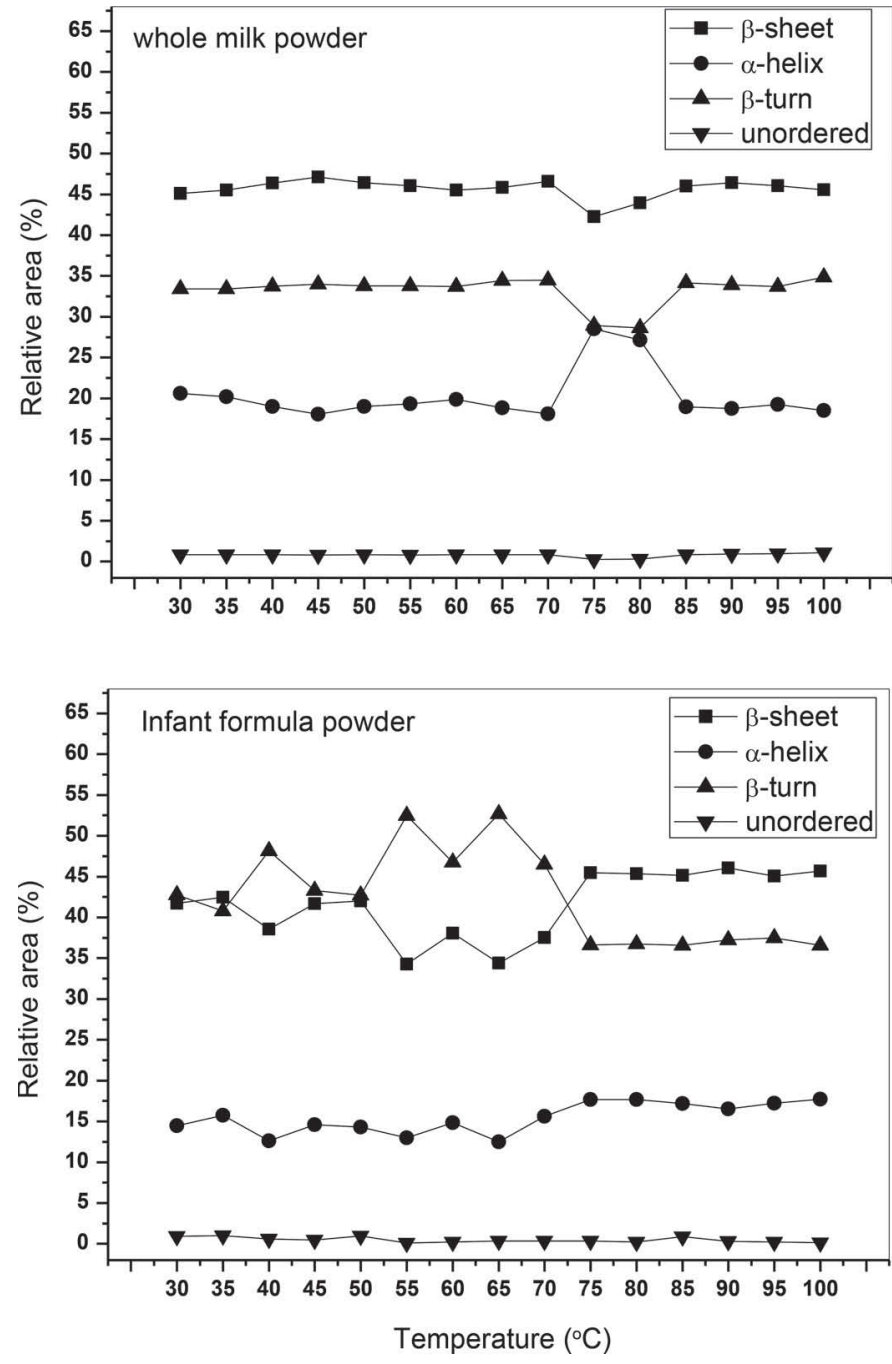

Figure 6. Relative areas of the bands fitted to the Fourierdeconvoluted spectra of whole milk and infant formula powders at different temperatures from 1,600 to $1,700 \mathrm{~cm}^{-1}$. Each band was assigned to the component of the secondary structure.

\section{REFERENCES}

Anema, S. G., D. N. Pinder, R. J. Hunter, and Y. Hemar. 2006. Effects of storage temperature on the solubility of milk protein concentrate (MPC85). Food Hydrocoll. 20:386-393.

Arrondo, J. L. R., and F. M. Goñi. 1999. Structure and dynamics of membrane proteins as studied by infrared spectroscopy. Prog. Biophys. Mol. Biol. 72:367-405.

Arrondo, J. L. R., A. Muga, J. Castresana, and F. M. Goñi. 1993. Quantitative studies of the structure of proteins in solution by Fourier-transform infrared spectroscopy. Prog. Biophys. Mol. Biol. 59:23-56.

Barth, A. 2007. Infrared spectroscopy of proteins. Biochim. Biophys. Acta 1767:1073-1101.

Barth, A., and C. Zscherp. 2002. What vibrations tell about proteins. Q. Rev. Biophys. 35:369-430.

Byler, D. M., and H. Susi. 1986. Examination of the secondary structure of proteins by deconvolved FTIR spectra. Biopolymers $25: 469-487$.
Carbonaro, M., and A. Nucara. 2010. Secondary structure of food proteins by Fourier transform spectroscopy in the mid-infrared region. Amino Acids 38:679-690.

De Marchi, M., V. Toffanin, M. Cassandro, and M. Penasa. 2014 Invited review: Mid-infrared spectroscopy as phenotyping tool for milk traits. J. Dairy Sci. 97:1171-1186.

Dong, A., P. Huang, and W. S. Caughey. 1990. Protein secondary structures in water from second-derivative amide I infrared spectra. Biochemistry 29:3303-3308.

Etzion, Y., R. Linker, U. Cogan, and I. Shmulevich. 2004. Determination of protein concentration in raw milk by mid-infrared Fourier transform infrared/attenuated total reflectance spectroscopy. J. Dairy Sci. 87:2779-2788.

Farrell, H. M., Jr., E. D. Wickham, J. J. Unruh, P. X. Qi, and P. D. Hoagland. 2001. Secondary structural studies of bovine caseins: Temperature dependence of $\beta$-casein structure as analyzed by circular dichroism and FTIR spectroscopy and correlation with micellization. Food Hydrocoll. 15:341-354.

Ford, J. E., B. A. Law, V. M. E. Marshall, and B. Reiter. 1977. Influence of the heat treatment of human milk on some of its protective constituents. J. Pediatr. 90:29-35.

Goormaghtigh, E., V. Raussens, and J. M. Ruysschaert. 1999. Attenuated total reflection infrared spectroscopy of proteins and lipids in biological membranes. Biochim. Biophys. Acta 1422:105-185.

Haug, A., A. T. Hostmark, and O. M. Harstad. 2007. Bovine milk in human nutrition-A review. Lipids Health Dis. 6:25.

Havea, P. 2006. Protein interactions in milk protein concentrate powders. Int. Dairy J. 16:415-422.

Kauppinen, J. K., D. J. Moffatt, H. H. Mantsch, and D. G. Cameron. 1981. Fourier self-deconvolution: a method for resolving intrinsically overlapped bands. Appl. Spectrosc. 35:271-276.

Kher, A., P. Udabage, I. Mckinnon, D. McNaughton, and M. A. Augustin. 2007. FTIR investigation of spray-dried milk protein concentrate powders. Vib. Spectrosc. 44:375-381.

Kim, H. H., and R. Jimenez-Flores. 1995. Heat-induced interactions between the proteins of milk fat globule membrane and skim milk. J. Dairy Sci. $78: 24-35$.

Kumosinski, T. F., and H. M. Farrell Jr. 1993. Determination of the global secondary structure of proteins by Fourier transform infrared (FTIR) spectroscopy. Trends Food Sci. Technol. 4:169-175.

Li-Chan, E. C. Y. 2007. Vibrational spectroscopy applied to the study of milk proteins. Lait 87:443-458.

Lönnerdal, B. 2003. Nutritional and physiologic significance of human milk proteins. Am. J. Clin. Nutr. 77:1537S-1543S.

Majzner, K., T. P. Wrobel, A. Fedorowicz, S. Chlopicki, and M. Baranska. 2013. Secondary structure of proteins analyzed ex vivo in vascular wall in diabetic animals using FT-IR spectroscopy. Analyst 138:7400-7410

Malacarne, M., F. Martuzzi, A. Summer, and P. Mariani. 2002. Protein and fat composition of mare's milk: Some nutritional remarks with reference to human and cow's milk. Int. Dairy J. 12:869-877.

McParland, S., E. Lewis, E. Kennedy, S. G. Moore, B. McCarthy, M. O'Donovan, S. T. Butler, J. E. Pryce, and D. P. Berry. 2014 Mid-infrared spectrometry of milk as a predictor of energy intake and efficiency in lactating dairy cows. J. Dairy Sci. 97:5863-5871.

Mizutani, Y., Y. Matsumura, H. Murakami, and T. Mori. 2004. Effects of heating on the interaction of lipid and zein in a dry powder system. J. Agric. Food Chem. 52:3570-3576.

Morand, M., F. Guyomarc'h, D. Legland, and M. H. Famelart. 2012. Changing the isoelectric point of the heat-induced whey protein complexes affects the acid gelation of skim milk. Int. Dairy J. 23:9-17.

Pappas, C. S., L. Sakkas, E. Moschopoulou, and G. Moatsou. 2015. Direct determination of lactulose in heat-treated milk using diffuse reflectance infrared Fourier transform spectroscopy and partial least squares regression. Int. J. Dairy Technol. 68:448-453.

Pelton, J. T., and L. R. McLean. 2000. Spectroscopic methods for analysis of protein secondary structure. Anal. Biochem. 277:167176. 
Puig, C., M. D. Pérez, L. Ros, L. Sánchez, and M. Calvo. 2003. Effect of processing on the composition of infant formulas. Milchwissenschaft 58:476-480.

Rutten, M. J. M., H. Bovenhuis, J. M. L. Heck, and J. A. M. van Arendonk. 2011. Predicting bovine milk protein composition based on Fourier transform infrared spectra. J. Dairy Sci. 94:5683-5690.

Soyeurt, H., D. Bruwier, J. M. Romnee, N. Gengler, C. Bertozzi, D. Veselko, and P. Dardenne. 2009. Potential estimation of major mineral contents in cow milk using mid-infrared spectrometry. J. Dairy Sci. 92:2444-2454.

Surewicz, W. K., H. H. Mantsch, and D. Chapman. 1993. Determination of protein secondary structure by Fourier transform infrared spectroscopy: a critical assessment. Biochemistry 32:389-394.

Susi, H., and D. Michael Byler. 1983. Protein structure by Fourier transform infrared spectroscopy: second derivative spectra. Biochem. Biophys. Res. Commun. 115:391-397.

Toffanin, V., M. De Marchi, N. Lopez-Villalobos, and M. Cassandro. 2015. Effectiveness of mid-infrared spectroscopy for prediction of the contents of calcium and phosphorus, and titratable acidity of milk and their relationship with milk quality and coagulation properties. Int. Dairy J. 41:68-73.

Visentin, G., A. McDermott, S. McParland, D. P. Berry, O. A. Kenny, A. Brodkorb, M. A. Fenelon, and M. De Marchi. 2015. Prediction of bovine milk technological traits from mid-infrared spectroscopy analysis in dairy cows. J. Dairy Sci. 98:6620-6629.

Wenstrup, M. J., M. Plans, and L. E. Rodriguez-Saona. 2014. Effect of a novel induction food-processing device in improving frying oil quality. Int. J. Food Sci. Technol. 49:2223-2229.

Yazdi, S. R., and M. Corredig. 2012. Heating of milk alters the binding of curcumin to casein micelles. A fluorescence spectroscopy study. Food Chem. 132:1143-1149.

Yu, P., and D. Damiran. 2011. Heat-induced changes to lipid molecular structure in Vimy flaxseed: Spectral intensity and molecular clustering. Spectrochim. Acta A Mol. Biomol. Spectrosc. 79:51-59.

Zhou, Q., S.-Q. Sun, L. Yu, C.-H. Xu, I. Noda, and X.-R. Zhang. 2006. Sequential changes of main components in different kinds of milk powders using two-dimensional infrared correlation analysis. J. Mol. Struct. 799:77-84. 